\title{
Early Printing Offices in Newmarket, Ontario
}

\author{
Carol Elder
}

Situated on rich agricultural land thirty-four miles north of Toronto, Ontario, Newmarket was first chosen as a settlement site in I80o by a prominent Quaker, Timothy Rogers. In its early years Newmarket was rather isolated, but the coming of the Ontario, Simcoe, and Huron Railroad in I 853 improved Newmarket's communication link with Toronto and the surrounding region, establishing the growing village as a major marketplace north of Toronto. Early in the I 850 a printing shop, the Era Office, was established in Newmarket. Over the next four decades the Era Office competed with three other establishments for the village's printing and publishing business. A brief history of these early printing offices is discussed below. A preliminary checklist of Newmarket imprints from the period discussed follows.

\section{The 'Era' Office}

In I 852 thirty-nine year old G.S. Porter established in his Newmarket stationery store a weekly newspaper called the New Era. ${ }^{1}$ The New Era was a five-column, four-page paper 'Devoted to News, Agriculture, Science, Morality, and Amusement.' Porter included articles from American, British, and Canadian newspapers and journals, transcripts of the provincial parliament, some correspondence, Toronto market information, anecdotes, jokes, and many advertisements. Before he began publishing the New Era in I 852 however, Porter had established his press in Newmarket: in 1846 he printed Hymns and Prayers for the Children of Sharon: To Be Sung in Worship on Sabbath Days for David Willson. A memorial 'To the Memory of David Lepard' who died on I5 October I839, exists, but there is no evidence that this broadside was printed prior to Hymns and Prayers.

By I 853 Porter had printed at least four books and numerous broadsides which were all written by David Willson who lived in Sharon, a village just north of Newmarket. In I8 I2 Willson seceded from the local Society of Friends and founded the Children of Peace, soon a thriving community with eclectic religious beliefs and practices. Willson was a voluminous writer who composed hymns, memorials, sermons political treatises, and 
monographs for the Children of Peace. Many of these were published in Newmarket.

In I 853 Porter sold his press and moved to Australia complaining that 'the Era venture had been inopportune, - the scarcity of money and the meagre education of potential readers were not conducive to interest in reading the current news, which, too, were scant. ${ }^{2}$ On June 20 of that year Erastus Jackson and E.R. Henderson bought Porter's printing establishment. Erastus Jackson later complained of the same business problems that Porter had; however, the new railway link with Toronto which brought news and money to Newmarket probably ensured in part the material success of Jackson's operation, and no doubt the establishment in I853 of a telegraph office helped to secure for Jackson a steady supply of current news.

According to an article published on Io January I9I9, in the Newmarket Era, Erastus Jackson was born 29 August I 829, in Merrickville, a village near Prescott in County Grenville. He was the son of a tanner and shoemaker and the grandson of a British regular who had been stationed at Niagara. In I 845 when he was sixteen years old, Jackson began a printing apprenticeship in Cobourg at the Canadian Christian Advocate office. When this office moved to Toronto in 1848 he went with it and completed his five year apprenticeship by I 850 . Jackson worked from I 850 to I 852 in Guelph as a journeyman in the Advertiser and Mercury offices and from I 852 to I 853 at the office of the North American in Toronto. In June, I853, Jackson and Henderson, also an employee of the North American, joined together to buy the New Era.

Jackson and Henderson's Newspaper, Book, Job, and General Printing Office moved from Porter's earlier location on Main Street to a new building on the south-west corner of Main and Mill Streets in the autumn of 1853 . In that year they printed Sacred Impressions of the Mind, in Praise and Prayer, Devoted to God in Worship by the Children of Peace in Sharon, another work written by David Willson, and probably broadsides for Willson and others in the Newmarket region, although none as yet has been located. In the summer of 1854 the Jackson-Henderson partnership broke up and Jackson became the sole proprietor and editor of the New Era. In I 858 the Era office moved to a new location on the south-west corner of Main and Ontario Streets.

Jackson firmly established himself as a major participant in community affairs, holding many offices in local churches, associations, and government. He became one of the village reeves in $\mathrm{I} 857$, served as a town councillor for twenty-five years, and was mayor from I890 to I 89I. His involvement in almost every aspect of community life in Newmarket must have helped to promote his printing business.

During Jackson's tenure as proprietor of the Era office he published at 
least twenty-five broadsides, pamphlets, and monographs, the vast majority written by Willson or other members of the Children of Peace. Like most other printing establishments of the time, the Era office also printed posters, bills, bills of lading, blank forms, and cards, sold books and stationary, and conducted 'Book Binding, In all its various branches executed with neatness and despatch' (Era, 5 January I 854). In the early days Jackson made money however he could, because printing alone was not a lucrative business and the credit system which widely prevailed made business operations difficult. $^{3}$

The Era, one of Jackson's primary concerns for thirty years, was issued weekly on Fridays at a cost of \$ I.50 per annum. It contained a business directory, literature, poetry, news from British, American, and Canadian newspapers, correspondence, local news, and copious advertisements. Although Jackson frequently complained because subscribers did not pay their bills promptly, growing circulation figures attest to the Era's success over the years. When Jackson first began printing the paper it circulated to fewer than three hundred persons, but, according to Meikle's Canadian Newspaper Directory or Advertisers' Guide, circulation increased by three hundred subscribers per year between I 854 and I $858 .{ }^{4}$ This would make the Era's circulation in I 858 approximately I, 200 at a time when Newmarket's population was only approximately I,000..$^{5}$ Either the Era was reaching many other communities in the region or Meikle's figures are somewhat exaggerated. By I856 Jackson was prosperous enough to enlarge his paper from six to seven columns and to buy a new press (Era, 28 December I 855 ). In I86I the name of the New Era was changed to The Newmarket Era and the paper was enlarged to eight columns. The Brighton Flag remarked upon the continuing success of the paper:

The NEWMARKET 'NEW ERA' comes to us this week considerably enlarged. - The New Era is a consistent Reform journal, and its increasing influence and circulation affords us pleasure and elicits our cordial congratulations (Era, I9 July I 86I).

Jackson still aimed to increase the circulation of the Era and he avidly promoted subscriptions. 'As an inducement to pay promptly in advance, for the year I862, we have made arrangements to supply such as do so, gratis, with the Rural Annual.... Now is the time to subscribe' (Era, 27 December I86I). Jackson probably found this ploy effective for he was still using it in I88I when subscribers who arranged to take the Newmarket Era and the Globe were offered cheaper rates (Era, 25 March I88I). In its early years the Era could be bought at the Era office or picked up at the post office in Newmarket; by I86I carrier boys were delivering the paper. The Era was 
also distributed to the towns surrounding Newmarket by train.

Although in many instances it is unknown if the proprietors of newspapers were practical printers, Erastus Jackson was a printer. He was helped by his son, Lyman George, who occasionally worked in the printing office as a young boy and later became a full time journeyman printer. For seven years he was a reporter, bookkeeper, and manager of the printing shop until I 883 when he succeeded his father as editor and proprietor. ${ }^{6}$ As was the usual practice, Jackson employed printing apprentices, including George Muir, the son of Alexander Muir who wrote 'The Maple Leaf Forever.' Although the dates of his employment are unknown, Muir apparently apprenticed for five years at the Era and then became foreman of the composing room, a position he held until I93 I. ${ }^{7}$

On I February r883, Erastus Jackson, the 'heroic inkslinger of North York' (Era, I6 February I 883), transferred his business to his son Lyman. In spite of continuing financial problems, Jackson had turned the Era office into a successful business. Initially he believed that the general populace's lack of education was a factor in the low number of newspaper readers. Over the years he came to see the newspaper not so much the concern of the educated man, but as a means for educating 'young men, and young women, for intelligent discharge of the duties of life' (Era, I 8 April I879). Jackson died on 6 January I919, and his obituary in the Newmarket Era of Io January I919, includes a long list of civic accomplishments not the least of which credited the New Era for Newmarket's commercial success over its rival, Holland Landing. Not only was Jackson influential in building and shaping Newmarket, but he left the town a newspaper which is still read today. ${ }^{8}$

\section{The 'Sentinel' Office}

On 20 December I 855, a new newspaper, the North York Sentinel, 'a weekly journal devoted to politics, literature, public improvement and general intelligence,' was established on Main Street opposite the 'Railroad Hotel' by Dr. Hunter, lawyer A. Boultbee, Benjamin Pearson, and George Hughes (Sentinel, I4 February I856). The Sentinel office advertised 'Job Printing Tastefully and expeditiously executed' (Sentinel, I4 February I856) and it too printed broadsides for David Willson. No books or pamphlets, however, have been located with the Sentinel imprint. The North York Sentinel was published weekly on Thursdays and, like the Era, cost \$ I.5O per annum. Its contents were similar to the Era's but the advertisements, for the most part, advertised foreign journals rather than local businesses. Both Newmarket papers presented politics from the Reformist point of view although this did not necessarily mean that they agreed on all political issues. Indeed, from the beginning the proprietors of the Sentinel and the Era railed at one another in print. 
The Sentinel did not survive long in Newmarket. It was still being printed on I 3 November I 856, but did not last into the new year. Perhaps because its content was so similar to the Era's it could not break into the Era's established clientele, or possibly financial difficulties closed the office.

\section{The 'Courier' Office}

For over a decade Jackson's printing office in Newmarket enjoyed a monopoly which was broken on 26 December I867, when G.M. Binns began to print a newspaper with a Conservative bias, The Newmarket Courier. ${ }^{9}$ It is possible that Binns had a printing office before he began publishing the Courier: he printed 'In Remembrance of Rachel, Wife of George Traviss' who had died in I863. Only three Binns imprints survive and all are written by members of the Children of Peace.

Published each Thursday, the Courier could be purchased at an annual subscription rate of \$ I.25, 25 4 less than the Era's annual price. It included a business directory, literature, wit and humour, foreign and local news, market prices, railway times, correspondence, editorials, and many advertisements. Although its content and format were similar to Jackson's newspaper, its Conservative political bias set it off from the Newmarket Era.

During its first years the Courier contained numerous advertisements for the many concerns of Binns who, like Jackson in his early years, did not rely solely on printing for a living. In I87 I Binns sold his printing office to Dr. Playter and in 1873 Playter sold the Courier to George H. Fox who renamed the paper the Newmarket Courier and North York Free Press in 1874 . He owned the venture until its demise in 1876 when it was bought out by the North York Reformer, a newly established Newmarket paper.

It is clear that Erastus Jackson and the various owners of the Courier were not friendly competitors. Binns and Jackson in particular waged war in their publications. In 1876 when the Courier was sold Jackson smugly reported:

On Thursday morning last, the Newmarket Courier - the organ of the Opposition in this Riding, breathed its last and died of depletion, with a slight parting struggle (Era, 2 I July I 876$)$.

\section{The 'North York Reformer' Office}

When Erastus Jackson opposed Dr. Widdifield, the official Reform candidate at the riding's Reform convention in I 875, Messrs. Oliver and Ratcliffe were inspired to establish a new newspaper, the North York Reformer, to serve the needs of the Reform party in the region. The Newmarket Era still professed to be Reformist, but it was now an opposition paper and competed fiercely with the Reformer.

The circulation of the Era in the late I870s is not known, but the paper 
must have faced a considerable challenge from the Reformer. The Reformer reported on 20 October 1876 , that it had already added nearly 300 subscribers to its circulation. By ro November 1876, it reported that it had almost doubled the old Courier subscription list. Thus within three months the Reformer may have had approximately 600 subscribers. The Reformer contended on 6 December 1876 , that the Era's subscription list was decreasing, but Jackson assured the Reformer that 'our subscription list is longer today than it ever was' (Era, I December I876).

From the outset the Reformer assured the local newspapers 'that our rivalry, - if it could be called our rivalry - shall be of a strictly honorable character' (Reformer, 3 August I 876) and although the editors asked their colleagues of the press to abstain from personal jibes when differences of opinion arose, soon acrimonious controversy was raging in print again. In I 877 Oliver left the Reformer and Mr. M. Baker of Whitchurch took his place. By I 878 Thomas Ratcliffe was the sole owner of the paper.

The Reformer continued to be published into the I880s according to one source; the last issue I have seen was dated 25 March I88I. ${ }^{10}$ However, McKim's Canadian Newspaper Directory of 1892 includes the Reformer in its list of Newmarket newspapers recording its circulation at 500 while the Era's was sworn to be I7I9. ${ }^{11}$ It appears that once again Jackson had withstood competition leaving the Era the victorious printing establishment in Newmarket.

NOTES

I Newmarket Era, I6 February I9I4. Further references are given in the text in parentheses. The New Era and Newmarket Era are abbreviated to Era.

2 History of the Town of Newmarket (Newmarket: N. p., I958), p. I54.

3 Ibid.

4 W. Meikle, The Canadian Newspaper Directory, or Advertisers' Guide ... (Toronto: Blackburn's City Steam Press, I 858), p. I8.

5 The Canada Directory for 1857-58 (Montreal: John Lovell, I857), p. 469; Meikle, Canadian Newspaper Directory, p. 57.

6 Commemorative Biographical Record of the County of York Ontario ... (Toronto: J.H. Beers \& Co., I907), p. 23.

7 History of Newmarket, p. 156.

8 In 1942 the Newmarket Era amalgamated with the Conservative Express-Herald to form the Era and Express. See Archives of Ontario, Newmarket Newspapers, microfilm N-276, reel I, p. 4. Today the paper is published as The Era.

9 According to Newmarket Newspapers, p. 4, the Courier became a Liberal paper as early as $\mathrm{I} 873$.

Io See Newmarket Newspapers, p. 4. The 25 March I88I, issue is located in the Canadiana Collection of the North York Public Library.

I I The Canadian Newspaper Directory (Montreal: A. McKim \& Co., I892), p. 208. 


\section{A Preliminary Checklist of Early Newmarket Imprints}

The following is a preliminary list of publications from Newmarket printing offices from the earliest known printing to I883, the year Erastus Jackson retired as the publisher of the Newmarket Era. Only items I have seen which have the imprint of one of the offices are listed. In addition, judging from their paper, typography, and layout, it seems likely that some forty broadsides, dating from I 842 to I 862 , at the Sharon Temple Collection were printed in Newmarket offices. These were not included because they lack a Newmarket imprint. The checklist is organized chronologically by printing offices. Newspapers are listed first, followed by other publications arranged in order of publication date.

LOCATION KEY

OSHT Sharon Temple, Sharon

OTAR Archives of Ontario

OTMCL Metropolitan Toronto Library, Baldwin Room

OTNY North York Public Library, Canadiana Collection

'Era' Office under G.S. Porter

The New Era I 852 -I 853

I 846

Willson, David. Hymns and Prayers for the Children of Sharon: To Be

Sung in Worship on Sabbath Days. Newmarket: G.S. Porter, I846.

Io8p. OSHT

Willson, David. Precaution for the People of Sharon. Newmarket: Porter, Printer, I846. Broadside. OsHT

I 847

Willson, David. The Sharon Meeting! Sharon: Porter, Printer, I847.

Broadside. osHT

I 848

Bazaar! Newmarket: Porter, Printer, I848. Broadside. OTMCL

I 849

Willson, David. Hymns and Prayers, Adapted to the Worship of God, in

Sharon. Newmarket: G.S. Porter, I 849. 207p. OsHT

I 852

Willson, David. A Collection of Items of the Life of David Willson, from 
the Year 1801 to 1852, by His Own Hand, for the People of Sharon, East Gwillimbury, County of York, C.W. Newmarket: G.S. Porter, I 852. Iop. OTMCL

I 853

Willson, David. Hymns of Praise, Containing Doctrine and Prayer, Adapted to the Worship of God in Sharon. Newmarket: G.S. Porter, New Era Office, I $853 \cdot 332$ p. OsHT

Undated

Willson, David. To the Memory of David Lepard, Son of Peter and Elizabeth Lepard, Who Was Killed at the Durham Meeting, on Yonge Street, on the 15th of October, 1839. Newmarket: Porter, Printer, [1839?]. Broadside. osHT

Willson, David. A Memorial of Mary, Daughter of Mr. Eli and Letitia Gorham, of Whitchurch, Who Departed This Life the 14th Day of June, 1846, Aged 20 Years. Newmarket: Porter, Printer, [I846?].

Broadside. OsHT

Willson, David. To the Memory of Jane, Daughter of Christopher and Elizabeth Summerville, Deceased July 26th, 1846, Aged One Year, Four Months, and Twenty-six Days. Newmarket: Porter, Printer, [I 846?]. Broadside. OsHT

Willson, David. Memorial of Matthew Lilly, of England, Deceased in Canada, May 21st, Aged 47 Years and 6 Months. Newmarket: G.S. Porter, Printer New Era Office, [1 847?]. Broadside. OsHT

Willson, David. A Loyal Song, Sung by the Inhabitants of Sharon; The Voters' Song; The Voters' Address to the Members of Parliament.

[Newmarket]: Porter, Printer, [1847?]. Broadside. OsHT

Willson, David. A Memorial of Mary Willson, Daughter of David and Phoebe Willson, and Wife of Charles Doan, Who Departed This Life, in Childbed, on the 6th Day of September, 1848, Aged 34 Years, 11 Months, and 21 Days. Newmarket: Porter, Printer, [I 848?]. Broadside. OsHT

Willson, David. Justice! A Hint from Sharon! [Newmarket]: Porter, Printer, [I 85 I?]. Broadside. OSHT

'Era' Office under E. Jackson and E.R. Henderson The New Era I 853-I 854

I853

Willson, David. Sacred Impressions of the Mind, in Praise and Prayer, Devoted to God in Worship by the Children of Peace in Sharon. 
Newmarket: Jackson \& Henderson's Newspaper, Book, Job, and General

Printing Office, I853. Io9p. OsHT

'Era' Office under E. Jackson

The New Era I854-I86I

The Newmarket Era I86I-I883

I 855

Catalogue of Books and Rules and Regulations of the Library of School

Section No. 1, Located in Newmarket. Newmarket: Printed at the New

Era Book and Job Office, I 855.39p. OTMCL

I 858

Christmas and New-Year's Presents, for the Holidays at Chas. J. Fisher's

Watch and Jewelry Store. Newmarket: 'New Era' Print, I 858.

Broadside. OTMCL

I 860

Geikie, W.B. The Aurora Mechanics' Institute and Library Association! A Lecture. Newmarket: New Era Print, I860. Broadside. OTAR

Willson, David. The Practical Life of the Author, from the Year 1801 to

1860. Newmarket: Erastus Jackson, Printer, I860. 8op. OTMCL

I 86 I

Rogers, E.D. and Baker, Thos. 'Knowledge Is Power.' Newmarket: Printed at the New Era Office, I86I. Broadside. OTAR

I 862

Willson, David. Remembrance of William Graham, Son of Amos H. and

Mary Ann Willson, Deceased December 23rd, 1861, - Aged 2 Years 3

Months and 19 Days! Newmarket: Newmarket Era Print, I 862.

Broadside. OTAR

I 865

Aurora Trade Guide and Advertiser! Vol. 1. Aurora, C.W. No. 1.

Newmarket: J.R. Breden, Publisher. E. Jackson, Cheap Newspaper, Book and Job Printer, I865. I6p. OTMCL

I 867

Credit Sale! Newmarket: E. Jackson, Proprietor, I867. Broadside. OTAR 
I 869

Society of Friends. An Appeal to the Christian Public on the Inconsistency of War with the Gospel Dispensation of the Society of Friends in Canada. Newmarket: Printed at the 'Newmarket Era' Book \& Job Office, I869. 9p. OTMCL

I 87 I

Cheap Sale! Newmarket: Era Print, I87I. Broadside. OTMCL

I 876

Principles and Regulations of the Religious and Charitable Society, Known as the Children of Peace Charitable Society, Incorporated, 1876. Newmarket: Printed at the Era Book and Job Office, I 876. Iop. OSHT

Insolvent Act of 1875. In the Matter of Israel Lundy 4 Reuben Lundy, Insolvents. Newmarket: Era Print, I 876. Broadside. OTMCL

I 879

Directions for the Guidance of Voters in Voting. Newmarket: Printed at the 'ERA' Steam Printing Establishment, I879. Broadside. OTAR

I 88 I

Dissolution of Partnership. Newmarket: Era Steam Press Print, I88 I. Broadside. OTNY

Undated

Willson, David. An Address, to the Clergy of Sects, Assemblies and Religious Bodies, Spiritual and Temporal, That Profess the Spirit of Christianity. Newmarket: New Era Print, [I855?]. Broadside. OsHT

Willson, David. Notice. To the Inhabitants of Eastville. Newmarket: Printed at Jackson's Job Office, [I 855 ?]. Broadside. OsHT

Willson, David. A Testimony to the Remembrance of James McCarty, Deceased June 22nd, 1856. Newmarket: E. Jackson, Book and Job Printer, [1 856 ?]. Broadside. OsHT

Willson, David. To the Memory of Hannah, Wife of Henry Carver, Deceased the 11th Day of February, 1857, Aged almost 69 Years, of Buckingham, Buck's County, Pennsylvania. Newmarket: Printed at E. Jackson's Book and Job Office, [1857?]. Broadside. OsHT

Willson, David. Remembrance of Mary Dunham, Daughter of John and Catharine Willson, Born in Dutchess County, State of New York, 1792, Widow of William Dunham, Deceased June 22nd, 1858. Newmarket: 
Printed at the 'New Era,' [1 858?]. Broadside. OsHT

Willson, David. Remembrance of Sabrey Lundy, Deceased January 4th, 1859, - Aged 21 Years and 16 Days. Newmarket: 'New Era' Print, [I 859 ? ]. Broadside. OsHT

Willson, David. The Faith and Practice, Belief and Disbelief of David Willson. Newmarket: Era Print, [I86r?]. Broadside. OsHT

Willson, David. An Epistle to the Society of Friends, Both Hicksite and Orthodox. Newmarket: Newmarket Era Print, [I 864?]. Broadside. OsHT

Willson, David. The Second Epistle to My Former Friends. Newmarket: Newmarket Era Print, [I 864?]. Broadside. OsHT

Dunham, Anna. In Memory of Harriet Doane, Wife of Enos Doane, Died Feb. 10, 1881 - Aged 67 y., 4m., 26d. Newmarket: Era Print, [I88I?]. Broadside. OsHT

N.D.G. In Memory of Dr. D.W. Lundy, Eldest Son of Judah and Elizabeth Lundy, of Sharon, Ont., Accidentally Killed near Albany, Ill., at the Meridosia Bridge Disaster, on the 21st Day of April, 1881, Aged 39 Years. Newmarket: Printed at the Era Office, [I88 I?]. Broadside. OsHT

Barker, Mary S. In Memory of Libbie, Wife of George Fogg, and Daughter of Robert and Martha Barker, Who Died July 5th 1881, after an Illness of 5 Years. Newmarket: Era Print, [188 I ?]. Broadside. OsHT

Dunham, Anna. Lines Written by Anna Dunham on the Death of Her Sister, Mrs. Elizabeth Graham. Newmarket: 'Newmarket Era' Print. Broadside. osHT

'North York Sentinel' Office

North York Sentinel December 20, I 855-1856

Undated

Willson, David. To the Memory of George Williams, Son of Orlin and Mareda Williams, Deceased October 5th, 1855, Aged 23 Years. Newmarket: 'North York Sentinel' Print, [1 855 ?]. Broadside. OsHT

Willson, David. To the Memory of Elias Pegg, Deceased March 17th, 1856.

Newmarket: 'North York Sentinel' Print, [I 856 ?]. Broadside. OSHT

The Testimony of David Willson and His Friends to the Memory of William Lockhart, Deceased, in Sharon, on the Evening of the Second of September, 1856. Newmarket: 'North York Sentinel,' [I 856 ?]. Broadside. OsHT

Willson, David. The Lord's Celebration. Newmarket: 'North York Sentinel' Print. Broadside. OsHT

\section{'Courier' Office}

The Newmarket Courier December 26, I867-I874 
The Newmarket Courier and North York Free Press I874-1 876

Undated

Willson, David. In Remembrance of Rachel, Wife of George Traviss, and Daughter of Joseph and Ellen Brammer, Deceased October 6th, 1863, Aged 27 Years, 5M., ↔ 27 D. Newmarket: Printed at the Newmarket Job Office, G.M. Binns, Proprietor, [1863?]. Broadside. OsHT

Willson, David. In Remembrance of William Graham Willson, Son of Job and Maria Willson. Deceased October 12th, 1865, Aged 1 Year, 2 Months and 21 Days. Newmarket: G.M. Binns, Printer and Stationer, [1865?]. Broadside. OsHT

To the Memory of Phoebe, Wife of Charles Graham, and Daughter of John D. and Maria Willson, Who Departed This Life, April 15, 1868, Aged 23 Years 43 Months. Newmarket: G.M. Binns, Printer, Courier Office, [I868?]. Broadside. OsHT

In Memory of John Herbert, Son of Charles and Phoebe Graham.

Newmarket: G.M. Binns, Printer. Broadside. OsHT

'North York Reformer' Office

North York Reformer i 876-1892?

I 862

Office Unknown

To the Ratepayers of the Village of Newmarket. Newmarket: N.p., I 862. OTMCL 